\title{
Peningkatan Aktivitas dan Hasil Belajar PKn Materi Kebebasan Berorganisasi Melalui Model Pembelajaran Team Accelerated Instruction
}

\section{Solikhatun ${ }^{*}$ \\ SD 1 Prambatan Lor Kudus}

\section{A R T I C L E I N F O}

Article history:

Received 12 December

2019

Received in revised form

01 January 2020

Accepted 30 January 2020

Available online 27

February 2020

\section{Kata Kunci:}

Aktivitas dan Hasil

Belajar, Team Accelerated

Instruction

Keywords:

Activity and Learning

Outcomes, Team

Accelerated Instruction

\begin{abstract}
A B S T R A K
Tujuan penelitian ini adalah untuk meningkatkan aktivitas dan hasil belajar PKn materi kebebasan berorganisasi melalui model pembelajaran team accelerated instruction pada siswa kelas $V$ SD 1 Prambatan Lor Kudus. Subjek penelitian adalah siswa kelas $V$ yang terdiri dari 12 siswa perempuan dan 9 siswa laki-laki. Penelitian ini dilaksanakan dalam dua siklus, masing-masing siklus terdiri atas dua kali pertemuan. Setiap siklus terdiri dari empat tahap yaitu perencanaan, pelaksanaan, observasi dan refleksi. Hasil penelitian ini menunjukkan bahwa aktivitas belajar siswa pada siklus I memperoleh rata-rata skor 20,43 dengan persentase $72,36 \%$ (sedang), siklus II meningkat menjadi 24,98 dengan persentase $89,10 \%$ (sangat tinggi). Sedangkan hasil belajar siswa pada siklus I nilai rata-rata kelas 77,86 dengan ketuntasan belajar klasikal sebesar $71,43 \%$. Pada siklus II nilai rata-rata kelas yang dicapai siswa 85 dengan ketuntasan belajar klasikal mencapai $85,71 \%$. Disimpulkan bahwa penerapan model pembelajaran team accelerated instruction terbukti dapat meningkatkan aktivitas dan hasil belajar PKn materi kebebasan berorganisasi pada siswa kelas V SD 1 Prambatan Lor Kecamatan Kaliwungu Kudus Semester II Tahun Pelajaran 2016/2017.
\end{abstract}

A B S T R A C T

The purpose of this study was to increase the activity and learning outcomes of Civics in freedom of association through the model of team learning accelerated instruction in fifth grade students of SD 1 Prambatan Lor Kudus. The subjects of the research were grade $V$ students consisting of 12 female students and 9 male students. This research was conducted in two cycles, each cycle consisting of two meetings. Each cycle consists of four stages, namely planning, acting, observing and reflecting. The results of this study indicate that the learning activities of students in the first cycle obtained an average score of 20.43 with a percentage of $72.36 \%$ (moderate), the second cycle increased to 24.98 with a percentage of $89.10 \%$ (very high). While student learning outcomes in the first cycle the average value of the class 77.86 with a mastery of classical learning by $71.43 \%$. In the second cycle the average grade of students who achieved 85 with classical learning completeness reached $85.71 \%$. It was concluded that the application of the accelerated instruction team learning model was proven to be able to improve the activities and learning outcomes of Civics in freedom of organization in fifth grade students of Prambatan Lor District Kaliwungu Kudus Semester II in the 2016/2017 Academic Year. 


\section{Pendahuluan}

Belajar merupakan suatu proses perubahan sikap dan perilaku yang berdasarkan pengetahuan dan pengalaman. Pendapat tersebut didukung oleh penjelasan Slameto (2010:2) bahwa belajar ialah suatu proses usaha yang dilakukan seseorang untuk memperoleh suatu perubahan tingkah laku yang baru secara keseluruhan sebagai hasil pengalamannya sendiri dalam berinteraksi dengan lingkungannya. Menurut Gagne (dalam Suprijono, 2012: 2) belajar adalah perubahan disposisi atau kemampuan yang dicapai seseorang melalui aktivitas. Perubahan disposisi tersebut bukan diperoleh langsung dari proses pertumbuhan seseorang secara alamiah. Menurut Isnaeni (2016) seseorang dikatakan belajar apabila terjadi perubahan pada dirinya akibat adanya latihan dan pengalaman melalui interaksi dengan lingkungan. Belajar adalah proses pengembangan dan kami dapat mengartikan ini sebagai sebuah proses pengembangan yang mengakibatkan atau menghasilkan perubahan tanggapan. Dengan begitu yang dimaksud belajar adalah adanya perubahan dalam tanggapan pada seseorang yang menuju ke arah perkembangan.

Aktivitas belajar merupakan segala kegiatan yang dilakukan dalam proses interaksi (guru dan siswa) dalam rangka mencapai tujuan belajar. Menurut Sardiman (2011:100) aktivitas belajar adalah aktivitas yang bersifat fisik maupun mental. Berdasarkan penjelasan tersebut, aktivitas belajar adalah kegiatan berupa fisik maupun mental yang dilakukan oleh seseorang untuk memperoleh ilmu atau kepandaian. Dalam kegiatan belajar, kegiatan fisik dan mental saling berkait. Aktivitas belajar merupakan suatu kegiatan yang dilakukan sebagai hasil perubahan pengetahuan, nilai-nilai, sikap, dan keterampilan pada siswa sebagai latihan yang dilaksanakan secara sengaja. (Sumantri dkk,2011:191). Jadi, aktivitas siswa dalam belajar adalah aktivitas yang bersifat fisik maupun mental ketika siswa mengikuti pembelajaran sehingga dapat membuahkan hasil belajar yang optimal.

Hasil belajar adalah perubahan-perubahan yang terjadi pada diri siswa, baik yang menyangkut aspek kognitif, afektif, dan psikomotor sebagai hasil dari kegiatan belajar (Susanto, 2013:5). Menurut Sudjana (2011:22), "hasil belajar adalah kemampuan-kemampuan yang dimiliki siswa setelah ia menerima pengalaman belajarnya." Menurut Rifa'i dan Anni (2009:2) belajar merupakan proses penting bagi perubahan perilaku setiap orang dan belajar mencakup segala sesuatu yang di pikirkan dan di kerjakan oleh seseorang. Belajar memegang peranan penting dalam perkembangan, kebiasaan, sikap, keyakinan, tujuan, kepribadian dan bahkan persepsi seseorang. Maka dengan menguasai konsep dasar tentang belajar, seseorang dapat mengetahui bahwa aktivitas belajar itu memegang peranan penting dalam proses psikologis untuk mencapai perubahan perilaku siswa yang berdampak pada hasil belajar. Hasil belajar merupakan perubahan tingkah laku pada diri siswa, yang dapat diamati dan dapat diukur dengan perubahan kognitif, afektif, dan psikomotorik. Perubahan dapat diartikan terjadinya peningkatan dan pengembangan menjadi lebih baik dibandingkan dengan sebelumnya, misalnya dari tidak tahu menjadi tahu, sikap tidak sopan menjadi sopan dan sebagainya (Purwanto, 2014:1.22). Dapat disimpulkan bahwa hasil belajar adalah perubahan tingkah laku yang dialami oleh siswa baik dari aspek kognitif, afektif, ataupun psikomotor yang dapat diukur dengan teknik-teknik atau kriteria tertentu yang dapat dituangkan dalam bentuk angka.

Pendidikan Kewarganegaraan merupakan materi yang memfokuskan pada pembentukan diri yang beragam, untuk menjadi warga negara Indonesia yang cerdas, terampil, berkarakter dan bertanggungjawab dalam berbagai kehidupan bermasyarakat, berbangsa dan bernegara.

Dalam proses pembelajaran PKn di kelas V SD 1 Prambatan Lor selama ini masih terlalu berorientasi terhadap penguasaan teori dan hafalan yang menyebabkan kemampuan belajar siswa menjadi terhambat. Metode pembelajaran yang terlalu berorientasi kepada guru (teacher centered), sehingga aktivitas siswa dalam pembelajaran masih rendah. Hal itu ditunjukkan dari kurang keterlibatan siswa dalam pembelajaran. Hal ini didukung dengan hasil tes formatif pada pembelajaran PKn materi kebebasan berorganisasi masih banyak siswa yang belum mencapai nilai di atas KKM yaitu 75 . Nilai ratarata ulangan formatif dari 21 siswa kelas $\mathrm{V}$, ada 10 siswa (47,62\%) yang mendapat nilai di atas KKM, sedangkan 11 siswa (52,38\%) masih di bawah KKM. Untuk mengatasi masalah tersebut, peneliti melakukan alternatif tindakan untuk memperbaiki kualitas pembelajaran PKn yaitu menerapkan model team accelerated instruction. Melalui model Team Accelerated Instruction (TAI) diharapkan dapat meningkatkan aktivitas dan hasil belajar siswa sehingga kualitas pembelajaran PKn akan meningkat. Team Accelerated Instruction (TAI) adalah model kooperatif sebagai usaha merancang sebuah bentuk pengajaran individual yang bisa menyelesaikan masalah-masalah yang membuat metode pengajaran individual menjadi tidak efektif. Dengan membuat para siswa bekerja dalam tim-tim pembelajaran kooperatif dan mengemban tanggung jawab mengelola dan memeriksa secara rutin, saling membantu satu sama lain dalam menghadapi masalah, dan saling member dorongan untuk maju. (Slavin, 2010: 189). Menurut Lasmi (2017) Media kooperatif tipe Team Accelerated Intruction (TAI) . Model pembelajaran 
kooperatif tipe TAI memiliki ciri khas, yaitu setiap siswa secara individual belajar materi pembelajaran yang sudah dipersiapkan oleh guru. Hasil belajar individual dibawa ke kelompok untuk didiskusikan dan dibahas dalam kelompok. Setelah itu dilaksanakan penilaian bersama-sama dalam kelompok. Semua anggota kelompok bertanggungjawab atas keseluruhan jawaban sebagai tanggungjawab bersama. Menurut Amal (2016) Model pembelajaran kooperatif tipe TAI (Team Accelerated Instruction) merupakan model pembelajaran yang menarik, karena menerapkan gabungan dari dua hal yaitu belajar dengan kemampuan masing-masing individu dan belajar kelompok. Inti dari pembelajaran TAI ini adalah pembelajaran dengan membentuk kelompok-kelompok belajar kecil yang heterogen terdiri dari 4 sampai 5 peserta didik dalam setiap kelompoknya, diikuti dengan pemberian bantuan secara individu bagi peserta didik yang memerlukannya. Setelah diimplementasikan model pembelajaran kooperatif tipe TAI,dalam proses pembelajaran diharapkan materi yang disampaikan akan lebih mudah dipahami oleh peserta didik, peserta didik juga merasa senang dan antusias selama proses pembelajaran. Menurut Ulyati (2018) Model belajar kooperatif learning tipe Team Asccelerated Intriction (TAI) dapat membuat siswa menerima siswa lain yang berkemampuan dan berlatar belakang yang berbeda. Metode ini juga telah terbukti dapat meningkatkan berfikir kritis serta meningkatkan kemampuan siswa dalam pemecahan masalah. Untuk menjamin heterogenitas keanggotaan kelompok, maka gurulah yang membentuk kelompok-kelompok tersebut. Jika siswa dibebaskan membuat kelompok sendiri maka biasanya siswa akan memilih teman-teman yang sangat disukainya. Ukuran besar kecilnya kelompok akan mempengaruhi kemampuan produktivitas kelompoknya. Menurut Rahmatikasari (2011) Model pembelajaran TAI Memiliki kelebihan dan kelemahan dalam pembelajaran. Kelebihan model pembelajaran TAI diantaranya membantu siswa yang kesulitan memahami materi pembelajaran memalui teman sebaya. Kelemahan TAI adalah siswa yang kurang pandai secara tidak langsung menggantungkan pada siswa yang pandai dan tidak ada persaingan kelompok.

Melalui model Team Accelerated Instruction (TAI), pebelajar mencoba menggali kemampuannya sendiri melalui pengalaman yang mereka miliki, kemudian bekerja sama dan mendiskusikannya, sehingga secara bersama-sama pebelajar dapat mengeksplorasi perasaan, sikap, nilai dan berbagai strategi pemecahan masalah. Melalui model Team Accelerated Instruction (TAI) diharapkan dapat menambah aktivitas siswa dalam proses pembelajaran dan meningkatkan hasil belajarnya sehingga kualitas pembelajaran PKn akan meningkat. Pembelajaran menggunakan model Team Accelerated Instruction membuat siswa menjadi aktif, saling mendukung dan saling membantu satu sama lain untuk berusaha keras karena mereka menginginkan timnya berhasil, namun tanggungjawab individu bisa dipastikan hadir karena adanya pembagian tugas dalam kelompok sebagai penjawab dan pengoreksi jawaban teman sendiri serta satu-satunya skor atau nilai yang diperhitungkan adalah skor/nilai akhir, sedangkan siswa melakukan tes akhir tanpa bantuan teman satu tim. Jadi apabila nilai akhir siswa meningkat dari pre-tes sebelumnya, dapat dikatakan bahwa kegiatan kelompoknya sukses (Huda, 2012:125-126). Keunggulan model TAI menurut Yusron (2010: 190-195) antara lain: 1) Dapat meminimalisir keterlibatan guru dalam pemeriksaan dan pengelolaan rutin; 2) Guru setidaknya akan menghabiskan separuh dari waktunya untuk mengajar kelompok-kelompok kecil sehingga akan lebih mudah dalam pemberian bantuan secara individu; 3) Operasional program tersebut akan sedemikian sederhananya sehingga para siswa di kelas tiga ke atas dapat melakukannya; 4) Para siswa akan termotivasi untuk mempelajari materi-materi yang diberikan dengan cepat dan akurat, dan tidak akan bias berbuat curang atau menemukan jalan pintas; 5) Programnya mudah dipelajari baik oleh guru maupun siswa, tidak mahal, fleksibel, dan tidak membutuhkan guru tambahan maupun tim guru; 6) Dengan membuat para siswa bekerja dalam kelompok-kelompok kooperatif, dengan status yang sejajar, program ini akan membangun kondisi untuk terbentuknya sikap-sikap positif dalam diri siswa.

Adapun tujuan penelitian ini adalah untuk meningkatkan aktivitas dan hasil belajar PKn materi kebebasan berorganisasi melalui model team accelerated instruction pada siswa kelas V SD 1 Prambatan Lor Semester II Tahun Pelajaran 2016/2017. Penelitian ini diharapkan dapat memberikan pengalaman belajar bermakna bagi siswa, sehingga dapat meningkatkan aktivitas dan hasil belajar PKn karena dapat berperan aktif dalam proses pembelajaran.

\section{Metode}

Penelitian tindakan kelas dilakukan di kelas V SD 1 Prambatan Lor semester II tahun pelajaran 2016/2017 dengan subjek penelitian 21 siswa. Penelitian dilaksanakan dalam dua siklus. Masing-masing siklus meliputi empat tahap kegiatan, yaitu perencanaan (planing), pelaksanaan tindakan (acting), pengamatan (observing) dan refleksi (reflecting). 
Dalam perencanaan ini meliputi kegiatan identifikasi masalah, menganalisis penyebab masalah dan menetapkan tindakan pemecahannya. Langkah selanjutnya membuat skenario pembelajaran dengan menyusun RPP yang terdapat proses pembelajaran model team accelerated instruction. Pelaksanaan tindakan (acting) dilaksanakan sesuai skenario pembelajaran yang telah direncanakan. Pada tiap-tiap siklus yaitu menerapkan pembelajaran model team accelerated instruction. Siklus II merupakan hasil pengembangan atas refleksi hasil siklus I.

Pengamatan (observing) pada kegiatan ini peneliti dibantu oleh satu orang observer untuk melaksanakan observasi terhadap pelaksanaan tindakan untuk mengetahui sejauh mana penguasaan siswa dalam pembelajaran. Observasi dilaksanakan bersamaan pelaksanaan tindakan dengan menggunakan lembar observasi yang telah dibuat. Aspek-aspek yang diamati adalah keaktifan siswa dan kinerja guru selama proses pembelajaran berlangsung serta hasil tes pada akhir siklus. Hasil analisis data yang dilaksanakan dalam tahap ini digunakan sebagai acuan untuk melaksanakan siklus berikutnya.

Refleksi (reflecting) hasil observasi yang meliputi aktifitas siswa selama proses belajar mengajar, hasil tes pada akhir siklus juga kendala-kendala yang dihadapi selama kegiatan pembelajaran dikumpulkan serta dikaji sehingga diperoleh hasil refleksi kegiatan untuk mengetahui perubahan yang terjadi selama menerapkan pembelajaran ini. Hasil analisis data yang dilaksanakan dalam tahap ini digunakan sebagai acuan untuk melaksanakan siklus berikutnya.

Teknik pengumpulan data dengan mendeskripsikan hasil tes dilakukan secara langsung kepada siswa untuk memperoleh data tentang hasil belajar siswa pada proses pembelajaran secara benar dan tepat. Metode tes digunakan untuk memperoleh data tentang tingkat kemampuan penguasaan materi pembelajaran sebelum dan sesudah pembelajaran.

Data yang sudah terkumpul kemudian dianalisis untuk mengukur indikator keberhasilan yang telah dirumuskan yaitu: 1) untuk mengukur keaktifan siswa menggunakan kriteria secara klasikal mencapai kategori baik atau lebih dari 75\%; 2) hasil belajar PKn dianggap meningkat apabila dapat mencapai ketuntasan belajar individual sebesar ( $\geq 75$ ) dan ketuntasan klasikal mencapai 80\%.

\section{Hasil dan Pembahasan}

Hasil penelitian tindakan kelas melalui model pembelajaran Team Accelerated Intruction diperoleh dari pengamatan proses pembelajaran dan penilaian hasil belajar PKn di kelas $\mathrm{V}$ yang terdiri dari deskripsi data tindakan siklus I dan deskripsi tindakan siklus II.

Berdasarkan hasil observasi aktivitas siswa pada pembelajaran PKn melalui model pembelajaran Team Accelerated Intruction pada siklus I mengalami peningkatan. Siswa terlihat antusias pada saat mengikuti kegiatan pembelajaran, siswa memperhatikan penjelasan guru. Namun masih ada beberapa siswa yang masih malu untuk bertanya atau mengeluarkan pendapatnya. Aktivitas siswa dalam diskusi cukup baik, tetapi sebagian kecil yang berani maju untuk mempresentasikan hasil kelompoknya. Aktivitas belajar siswa pada siklus I sebesar 72,36\% dengan persentase aktivitas pertemuan I sebesar 70,24\% serta persentase aktivitas pertemuan II sebesar 75,68\%. Dari data tersebut dapat disimpulkan bahwa hasil observasi aktivitas belajar siswa belum berhasil untuk mencapai indikator yang ditentukan pada aktivitas belajar siswa yaitu sebesar $\geq 75 \%$ meskipun pada aktivitas belajar siswa pada kategori sedang atau cukup baik.

Hasil penelitian siklus I dengan menerapkan model pembelajaran team accelerated instruction, diperoleh data sebagai berikut: dari 21 siswa, 15 siswa atau 71,43\% mengalami ketuntasan belajar, dan yang 6 siswa atau 28,57\% belum tuntas dalam belajar. Ada peningkatan sebesar 23,81\% atau 5 siswa yang sudah tuntas. Dengan demikian ketuntasan belajar pada siklus I cukup baik, namun masih perlu diperbaiki lagi supaya hasilnya sesuai dengan indikator keberhasilan yang diharapkan.

Berikut rekapitulasi hasil belajar siswa pada siklus I yang disajikan dalam bentuk Tabel.

Tabel 1. Hasil Belajar Siswa Siklus I

\begin{tabular}{lccc}
\hline \multicolumn{1}{c}{ Rentang nilai } & Frek & Jumlah nilai & Persentase \\
\hline $93-100$ & 2 & 200 & $9,52 \%$ \\
$85-92$ & 5 & 450 & $23,81 \%$ \\
$75-84$ & 8 & 615 & $38,10 \%$ \\
$66-74$ & 2 & 140 & $9,52 \%$ \\
$57-65$ & 4 & 420 & $19,05 \%$ \\
$48-56$ & - & - & - \\
\hline Jumlah & $\mathbf{2 1}$ & $\mathbf{1 6 3 5}$ & $\mathbf{1 0 0 \%}$
\end{tabular}


Jumlah Total Nilai

\begin{tabular}{lc}
\hline Nilai rata-rata kelas & $\mathbf{7 7 , 8 6}$ \\
\hline Tuntas belajar & $\mathbf{7 1 , 4 3}$ \\
\hline Belum tuntas belajar & $\mathbf{2 8 , 5 7 \%}$ \\
\hline
\end{tabular}

Berdasarkan data hasil tes formatif siklus I menunjukkan adanya peningkatan. Pembelajaran yang dilakukan pada prasiklus hanya mencapai ketuntasan $47,62 \%$ setelah diadakan tindakan siklus I ketuntasan menjadi 71,43\%.Beberapa kekurangan di antaranya: 1) masih banyak siswa yang pasif, baik didalam bertanya kepada guru maupun kepada kelompoknya, 2) kelompok yang melakukan presentasi masih sedikit, 3) partisipasi siswa dalam diskusi kelompok kurang maksimal. Karena ketuntasan belajar belum mencapai $80 \%$ dari jumlah siswa maka diadakan tindakan pembelajaran siklus II dengan cara:1) mengoptimalkan materi dengan menerapkan model team accelerated instruction, 2) meminta kepada seluruh siswa untuk aktif dalam berdiskusi, 3) memberikan motivasi pada siswa, supaya lebih percaya diri dalam mempresentasikan hasil kelompoknya dengan penguatan positif.

Kegiatan pembelajaran siklus II berlangsung sangat efektif, siswa antusias melakukan diskusi dan terjadi interaksi harmonis dalam satu kelompok maupun antar kelompok. Siswa saling menanggapi hasil temuan kelompok lain secara rasional dan berpendapat secara logis melalui model team accelerated instruction.

Pada tindakan pembelajaran siklus II menunjukkan peningkatan pada hasil belajar siswa. Ketuntasan belajar klasikal yang dicapai sebesar $85,71 \%$ artinya masih ada 3 siswa $(14,29 \%)$ belum tuntas/mencapai nilai KKM. Hal ini dapat dilihat pada Tabel 2 berikut.

Tabel 2. Hasil Belajar Siswa Siklus II

\begin{tabular}{lccc}
\hline \multicolumn{1}{c}{ Rentang nilai } & Frek & Jumlah nilai & Persentase \\
\hline $93-100$ & 5 & 500 & $23,81 \%$ \\
$85-92$ & 6 & 530 & $28,57 \%$ \\
$75-84$ & 7 & 555 & $33,33 \%$ \\
$66-74$ & 3 & 200 & $14,29 \%$ \\
$57-65$ & - & - & - \\
$48-56$ & - & - & - \\
\hline Jumlah & $\mathbf{2 1}$ & $\mathbf{1 7 8 5}$ & $\mathbf{1 0 0 \%}$ \\
Jumlah Total Nilai & & & $\mathbf{1 7 8 5}$ \\
\hline Nilai rata-rata kelas & & & $\mathbf{8 5 , 7 1}$ \\
\hline Tuntas belajar & & & $\mathbf{1 4 , 2 9 \%}$ \\
\hline Belum tuntas belajar & & & \\
\hline
\end{tabular}

Pada Tabel 2 menunjukkan bahwa hasil tes formatif siklus II mengalami peningkatan. Pencapaian nilai rata-rata kelas pada siklus I mencapai 77,86 dan pada siklus II meningkat menjadi 85. Pada siklus II terdapat jumlah siswa yang tuntas belajar yaitu 18 siswa dengan persentase ketuntasan belajar 85,71\%, sedangkan 3 siswa tidak tuntas belajar dengan persentase 14,29\%. Hal ini menunjukkan adanya peningkatan dari siklus I ke siklus II mencapai 14,28\%. Hasil ini termasuk memuaskan karena sudah memenuhi indikator, yang telah ditetapkan yaitu ketuntasan klasikal belajar siswa minimal 80\%.

Pada pembelajaran sebelum tindakan penelitian, peneliti hanya mengandalkan metode konvensional yaitu ceramah, tanya jawab, dan pemberian tugas, sehingga hasil yang dicapai adalah siswa yang memperoleh nilai 75 ke atas hanya 10 dari 21 siswa atau 47,62\%. Dengan nilai terendah 40, nilai tertinggi 90 dan nilai rata-rata 68,57. Berdasarkan hasil tersebut peneliti bermaksud meningkatkan hasil belajar PKn melalui model team accelerated instruction.

Hasil pembelajaran pada siklus I dapat diketahui bahwa dalam tes formatif nilai rata-rata kelas sebesar 77,86 dan persentase ketuntasan belajar baru mencapai 71,43\%. Nilai ketuntasan minimal (KKM) yang telah ditentukan yaitu 75, sedangkan kriteria ketuntasan belajar klasikal yakni 80\%. Dari 21 siswa hanya 15 siswa yang memenuhi nilai KKM dan masih ada 6 siswa yang mendapat nilai di bawah 75 . Dengan demikian masih banyak siswa yang belum mencapai KKM dan belum mencapai ketuntasan belajar klasikal. Hal ini menunjukkan bahwa hasil belajar siswa masih dikatakan belum tuntas karena belum mencapai indikator ketuntasan secara klasikal yang telah ditetapkan yaitu $80 \%$.

Secara keseluruhan aktivitas belajar siswa pada siklus I sebesar $72,36 \%$ dengan persentase aktivitas pertemuan I sebesar 70,24\% serta aktivitas pertemuan II sebesar 75,68\%. Dari data tersebut dapat disimpulkan bahwa hasil observasi aktivitas belajar siswa belum berhasil mencapai indikator yang ditentukan, yaitu $\geq 75 \%$ meskipun pada aktivitas belajar siswa pada kategori sedang atau cukup baik. 
Peneliti merefleksi sebab-sebab kegagalan dalam tindakan siklus I, sebagai berikut: 1) siswa kurang terlibat dalam pembelajaran, 2) guru lebih aktif sendiri dalam pembelajaran, 3) kegiatan diskusi kelompok belum berjalan secara optimal, karena kerja kelompok yang dilakukan masih didominasi siswa yang pandai, 4) siswa kurang siap untuk mempresentasikan hasil diskusi kelompoknya. Cara yang tepat digunakan untuk mengatasi hal tersebut: 1) peneliti meminta kepada seluruh siswa untuk aktif dalam berdiskusi, 2) memberikan motivasi pada siswa untuk lebih percaya diri dalam mempresentasikan hasil diskusi dengan penguatan positif, 3) pada saat presentasi kelompok, peneliti mengajak seluruh kelompok untuk mendengarkan kemudian menanggapi hasil diskusi kelompok yang maju presentasi.

Pelaksanaan tindakan siklus II diperoleh nilai tertinggi 100 dan nilai terendah 60 dengan nilai ratarata 85 serta ketuntasan klasikal 85,71\%. Hal tersebut menunjukkan peningkatan jika dibandingkan dengan hasil belajar pada siklus I dengan nilai terendah 50 dan nilai tertinggi 100 dengan nilai rata-rata 77,86 serta ketuntasan klasikal sebesar 71,43\%.

Pada tindakan siklus II, terjadi perubahan sikap dan keterampilan belajar berupa keberanian siswa mengungkapkan pendapatnya dengan menggunakan catatan singkat dan ringkasan. Sebagian besar berani tampil di muka kelas untuk presentasi karena siswa yakin hasil pekerjaannya tidak salah. Siswa dapat melakukan komunikasi antar kelompok secara maksimal, artinya yang dulunya pendiam mau tidak mau harus aktif karena penerapan model team accelerated instruction diharapkan terjalin komunikasi aktif antar siswa, semangat kebersamaan dan kerjasama, partisipasi dalam kerja kelompok, dan memaksimalkan hasil belajar siswa serta dukungan dan penguatan guru.

Penerapan model pembelajaran team accelerated instruction pada mata pelajaran PKn dapat meningkatkan aktivitas dan hasil belajar siswa. Hal ini dibuktikan dengan adanya peningkatan nilai ratarata kelas dan peningkatan ketuntasan hasil belajar pada siklus I dan siklus II. Disamping itu motivasi siswa dalam belajar juga mengalami perubahan yang dibuktikan dengan aktivitas siswa dalam melakukan kerjasama kelompok dan berdiskusi. Hasil pembelajaran mengalami peningkatan sehingga indikator keberhasilan telah tercapai karena siswa yang mengalami ketuntasan belajar lebih dari $80 \%$.

Pelaksanaan pembelajaran melalui model team accelerated instruction dalam pelajaran PKn dapat meningkatkan aktivitas dan hasil belajar siswa kelas V SD 1 Prambatan Lor Kudus. Keberhasilan belajar terletak pada nilai hasil tes siswa pada setiap siklusnya. Dengan demikian penelitian tindakan kelas ini dikatakan berhasil.

\section{Simpulan dan Saran}

Simpulan dari penelitian tindakan kelas yang telah dilaksanakan adalah: Penerapan model team accelerated instruction dapat meningkatkan aktivitas dan hasil belajar PKn materi kebebasan berorganisasi pada siswa kelas V SD 1 Prambatan Lor Kudus. Hal itu terlihat dari ketuntasan hasil belajar siswa pada siklus II mencapai $85,71 \%$, dan respon siswa terhadap penerapan model team accelerated instruction sangat baik. Hal itu terlihat dari semangat siswa selama mengikuti kegiatan pembelajaran dengan menggunakan model tersebut.

Berdasarkan hasil penelitian tersebut maka perlu kiranya penerapan model team accelerated instruction sebagai strategi pembelajaran di sekolah-sekolah, untuk meningkatkan hasil belajar PKn dan semua mata pelajaran yang lain pada umumnya.

Bagi lembaga pendidikan, hendaknya memberikan sarana dan prasarana, fasilitas serta motivasi bagi guru yang akan menerapkan model pembelajaran team accelerated instruction atau model lain sehingga pembelajaran berlangsung optimal.

Bagi Guru, agar menerapkan model team accelerated instruction ini dapat didayagunakan secara optimal, maka guru dalam setiap pembelajaran perlu merencanakan pendekatan atau strategi dan mempersiapkan media pembelajaran yang kreatif dan inovatif sehingga siswa menjadi lebih tertarik dan pembelajaran akan menjadi lebih kondusif dan bermakna.

Bagi siswa hendaknya penerapan model team accelerated instruction selalu melaksanakan kegiatan pembelajaran dengan sebaik-baiknya. Pada setiap pembelajaran yang diberikan guru, siswa seharusnya memperhatikan kerjasama untuk memecahkan suatu masalah dalam materi pembelajaran akan lebih mudah jika diselesaikan secara kelompok, dan siswa harus percaya diri dalam kegiatan pembelajaran sehingga kegiatan pembelajaran berjalan dengan aktif dan tujuan pembelajaran dapat tercapai secara optimal. 


\section{Daftar Rujukan}

Amal, Ardiansya, A., Herman, Abdul Haris. 2016. Pengaruh Model Pembelajaran Team Accelerated Instruction terhadap Hasil Belajar Fisika Peserta Didik Kelas X SMA Negeri 2 Watansoppeng. Jurnal Sains dan Pendidikan Fisika, Vol. 12 No. 1 Hal. 37-43. Tersedia Pada: https://ojs.unm.ac.id/JSdPF/article/view/2029/1081.

Huda, Miftahul. 2012. Cooperative Learning Metode Teknik Struktur dan Model Penerapan. Yogyakarta: Pustaka Belajar.

Isnaeni, Hengki Danang. 2016. Penerapan Model Pembelajaran Kooperatif Tipe Team Accelerated Instruction (TAI) untuk Meningkatkan Minat dan Prestasi Belajar Siswa Kelas XII IPA 2 SMA Negeri 3 Bojonegoro Pada Pokok Bahasan Matrik Tahun Pelajaran 2012/2013. Jurnal Edutama Vol. 2 No. 2 Hal. 2 1-16. Tersedia Pada: http://ejurnal.ikippgribojonegoro.ac.id/index.php/JPE/article/download/19/19.

Lasmi. 2017. Penerapan Model Pembelajaran Kooperatif Tipe Team Accelerated Instruction (TAI) yang Berorientasi Teori Apos pada Materi Fungsi Kuadrat di Kelas X-MIA MAN 2 Banda Aceh. Al Khawarizmi, Vol. 1, No. 1 Hal. 33-50. Tersedia Pada: https://jurnal.arraniry.ac.id/index.php/alkhawarizmi/article/view/1730/1267.

Purwanto. 2014. Evaluasi Hasil Belajar. Yogyakarta: Pustaka Belajar.

Rahmatikasari, U. (2013). Penerapan tipe Team Assisted Individualization (TAI) dalam Peningkatan Pembelajaran Matematika tentang Bilangan Pecahan Siswa Kelas V SD. Kalam Cendekia PGSD Kebumen, 3(2).

Rifa'i, Achmad dan Catharina Tri Anni. 2009. Psikologi Pendidikan. Semarang: UNNES Press

Sardiman. 2011. Interaksi dan Motivasi Belajar Mengajar. Jakarta: Rajawali Pers.

Sudjana, Nana. 2011. Penilaian Hasil Proses Belajar Mengajar. Bandung: Remaja Rosdakarya

Sumantri, Mulyani dkk. 2011. Strategi Belajar Mengajar. Bandung: Maulana.

Susanto, Ahmad. 2013. Teori Belajar dan Pembelajaran di Sekolah Dasar. Jakarta: Kencana Prenada Media Group

Slameto. 2010. Belajar dan Faktor-faktor yang Mempengaruhinya. Jakarta: Rineka Cipta

Suprijono, Agus. 2012. Cooperative Learning, Teori \& Aplikasi PAIKEM. Yogyakarta: Pustaka Belajar

Slavin, Robert E. 2010. Cooperative Learning Teori, Riset, dan Praktik. Bandung : Nusa Media.

Ulyati. 2018. Upaya Meningkatkan Hasil Belajar Matematika Melalui Metode Kooperatif Tipe Team Accelarated Intruction (TAI). JKPM (Jurnal Kajian Pendidikan Matematika) Vol. 03, No. 02 Hal. 165-176. Tersedia Pada: http://journal.lppmunindra.ac.id/index.php/jkpm/.

Yusron, N. 2010. Cooperative learning Teori, Riset dan Praktik. Bandung: Nusa Media. 